\title{
Responsiveness of Rural and Urban Land Uses to Land Rent Determinants in the U.S. South
}

\author{
Ian Hardie, Peter Parks, Peter Gottleib, and David Wear
}

ABSTRACT. Ricardian und von Thünen land rent models are combined into a single land use share model including farm, forest, and urban land uses. The land share model is applied to the Southern United States, and elasticities are extracted that measure land share response to changes in population, income, land values, prices, and costs in counties with different degrees of urbanization. The study explores the effect of treating either rural or urban land as a residual use. While this practice is common in existing land use studies, it is found to significantly affect parameter estimates in this county-level analysis. (JEL R 14)

In a paper prepared for a forthcoming Yearbook of Environmental Economics, Bockstael and Irwin observe that "Often policies of the public sector seek to affect land uses by providing incentives or disincentives that affect landowners' land use decisions. Perhaps even more often, land use decisions are affected by policies that have been designed to address completely different social concerns, but the consequences for land use change can be both unintended and severe" (1999, 14). Policy effects, whether intended or unintended, also may vary substantially across space and through time, and may combine and interact in ways that make a targeted analysis of a particular policy incomplete. As a consequence, there is value in knowing how land use is responding to change in population, income, farm revenue, timber establishment cost, and other land use determinants. Such positive results can summarize the combined effects of existing policies. They also can indicate where and how much land use might change if new policies affect the determinants of land use.

This paper presents a county-level land use analysis for 1,459 counties in the U.S. South. The analysis is based on two traditional land rent models: a Ricardian rent model for rural land use and a von Thünen location rent mode1 for urban land use. The
Ricardian model has seen extensive use in the agricultural economics literature (Caswell and Zilberman 1985; Chavas and Holt 1990; Claassen and Tegene 1999; Hardie and Parks 1997; Lichtenberg 1989; Plantinga 1996; Wu and Segerson 1995). The von Thünen model has served as a standard formulation in the analysis of urban economic growth (Alonso 1964; Anas 1978; Arnott 19SO; Capozza and Helsley 1989; Fajita 1982; Mills 1967; Muth 1967; Wheaton 1982a). Each of these rent models can be separately transformed into an acreage allocation model that directly relates land use shares to land rent determinants. They also can be combined into an integrated land share model that explicitly includes both rural and urban land use. We employ these land share models to obtain reduced form elasticities that relate change in land use shares to change in rent determinants. The elasticities are used to explore land use response in the South in counties ranging from the very rural (one person per 35 acres) to the very urban (one person per two-thirds of an acre).

The analysis is motivated in part by the prevailing practice of considering only rural or urban land in the economic analysis of land use. Separating use in this way may be defensible if urban land values dominate agricultural land values, and if urban land use depends only on variables that are exogenous to rural land use decisions. Then rural land might be treated as land not yet needed for

Ian Hardie is a professor in Agricultural and Resource Economics, University of Maryland. Peter Parks is an associate professor in Agricultural Economics, Cook College, Rutgers University. Peter Gottleib was a research assistant in Agricultural and Resource Economics, University of Maryland. David Wear is a research forester at the Southern Forest Experiment Station, U.S. Department of Agriculture, Forest Service. This research was funded by the Southern Forest Experiment Station and by the Rutgers and Maryland Agricultural Experiment Stations. 
urban use, as has been done in most studies of the growth of urban areas. Rural land use decisions might be modeled separately for a reduced land base, as has been done in most analyses of agricultural acreage supply response. I But analytical separations of this sort will be consistent with landowner behavior only if landowners also separate land use decisions into rural and urban categories. If they do not, the analytical separation may impose unjustified restrictions on the land use decision. Using models that incorrectly restrict land use decisions may lead to forecasts of (1) success for what may in fact be ineffective policies; or (2) failure for what may in fact be effective policies. Correct specification of land use decisions consequently is needed for the analysis of landrelated environmental and resource policies.

To explore this possibility, we test hypotheses that estimates from separate rural and urban land rent models are similar to estimates from a combined rural-urban model. These tests are specific to a region, to our particular model formulation, and to the level of aggregation embodied in a county-level analysis. Even so, finding significant differences in results for a region as large and diverse as the South should raise doubts about the current practice of omitting either rural or urban land from a land use analysis. It is not difficult to integrate the traditional land rent formulations into a single land use share model, and doing so may protect against an unwarranted circumscription of land use choice.

Distinguishing features of the analysis include a geographic definition of total land area, broad but exhaustive categories of land use, data aggregation to the county level, and use of pooled cross-sectional census data. Studies by Alig (1986), Hardie and Parks (1997), Miller and Plantinga (1999), Parks and Murray (1994), Plantinga (1996), and Wu, Mapp, and Bernardo (1996) have similar characteristics. The geographic definition of the land base contrasts with the commodity-based definition (e.g., corn land, wheat land) of most agricultural acreage supply response analyses. Geographic or area-based analyses ensure that acreage increases in one use category are offset by acreage decreases in other rent-producing uses. These opportunity costs of land use change generally are omitted from commodity-based analyses. But area-based analyses also typically include a residual land use category with no assigned rent, and this may cause the opportunity cost of changing land use to be understated.

The behavioral assumptions of the study have been employed in many acreage supply response models. They include competitive land markets and quasi-rent maximization on the part of price-taking landowners." Land use studies that do not adopt these behavioral assumptions include studies that allocate land so as to maximize consumer and producer surplus (Adams et al. 1993, Alig, Adams, and McCarl 1998, Chang et al. 1992), and studies that rely on cadastral and geographically referenced landscape data to determine probabilities of land use at the parcel level (Bockstael 1996, Landis 1995, Bradshaw and Muller 1998).

Parameter estimates are obtained using modified binomial (Amemiya and Nold 1975) and multinomial logit procedures (Parks 1980). These estimation procedures respect the fixed nature of the county land base. They allow for error in all model variables. This latter attribute is particularly important because census sampling procedures are known to produce significant measurement error when aggregation is at the county level.

These analyses include expected profit models (Chavas, Pope, and Kao 1983; Lee and Helmberger 1985; Lidman and Bawden 1974; Shideed. White. and Brannen 1987) and farm product market models (Brandt, Kruse, and Todd 1992; Miranda, Novak, and Lerohl 1994; Shonkwiler and Maddala 1985). Analysts have emphasized measurement of expected output price (Gallager 1978; Gardner 1976; Stein 1981), alternative ways to model the effect of farm commodity price supports (Houck et al. 1976; McIntosh and Shideed 1989; Morzuch, Weaver, and Helmberger 1980). and the riskiness of farm production (Babcock 1990; Chavas and Holt 1990). All of these analyses have been for a specific crop or set of crops, and land area has been restricted to acreage used to produce the $\operatorname{crop}(\mathrm{s})$.

2 Prices are taken to be both current and exogenous in these models. They are treated as expectations in most agricultural supply response models, and as endogenous in the farm product market formulations. 


\section{INTEGRATING VON THÜNEN AND RICARDIAN LAND RENT MODELS}

Most rural land share models postulate quasi-rent maximization by representative producers who use land as a productive factor and who face competitive market prices for non-land inputs and outputs. Under these conditions, a single land use would maximize quasi-rent if land were homogeneous. Different land uses can co-exist if heterogeneous land quality causes product yields and quasirents to vary over parcels. This classical Ricardian rent explanation of the simultaneous presence of different productive uses forms the theoretical foundation for many of the rural land use analyses.

Land use studies typically begin with given categories of land use. If such prior categorization is to be consistent with the maximization of Ricardian quasi-rents, restricted profit functions must exist for each land use category. Then the use of each parcel of land can be detennined by choosing the category that maximizes quasi-rent from among the relevant competing land use categories.

Within this context, quasi-rent from land can be defined as

$\pi^{*}=\max \left(\pi^{* 1}, ., \pi^{* J}\right)$,

where $j=\mathrm{I}, \ldots, J$ represents land use categories and $\pi^{* j}$ represents a restricted profit function for category $\mathrm{j}$. Rents accruing to each land use will be

$\pi^{*}(\boldsymbol{P}, Q)=\boldsymbol{P} \boldsymbol{x}^{*}(\boldsymbol{P}, Q)^{\prime}$

where $\boldsymbol{P}$ is an exogenous vector of input and output prices, $\boldsymbol{x}^{* 1}$ is a vector of profit-maximizing output supplies and input demands, and $Q$ is an exogenous index of land quality. Prior categorization of land use will restrict the elements of $\boldsymbol{x}^{* \prime}$ and $\boldsymbol{P}$ to subsets of outputs and inputs. Omission of land as an input will allow the $\pi^{j}$ to be interpreted as quasirents (Palmquist 1989).

When total acreage is fixed, the land allocated to each use may be expressed as proportions or shares. If, in addition, the land quality index $\mathrm{Q}$ is monotonic and continuous, profit-maximizing shares $\varphi_{i}, \mathrm{j}=1, \ldots, J$, may form compact sets that span $Q$. Land use change then would occur at land use boundaries, when changes in profits cause these boundaries to shift. Necessary conditions for this "margins" outcome include constant returns to scale production technologies and restricted profit functions that are concave in $Q$ (Lichtenberg 1985).

Taking these conditions to be satisfied allows the Ricardian rent model to be reduced to the land shares model

$$
\begin{aligned}
\varphi^{\prime}(Q) & =F_{j}(\boldsymbol{P}, Q) \text { for } j=\mathrm{I}, \ldots, \mathrm{J}-1 \\
\varphi^{J} & =1-\sum_{j=1}^{j-1} \varphi^{j}(Q)
\end{aligned}
$$

(Hardie and Parks 1997). This model directly relates the proportion of land in a particular productive use to market prices and land quality. The direction of change in the shares resulting from change in $\boldsymbol{P}$ and $Q$ can be deduced from the comparative statics of the underlying rent model (Lichtenberg 1989).

Equation 3 shows that the land shares model incorporates a residual land category composed of land "left over" from $J=1$ categories of explicitly defined land use. Thus it is possible to formulate a Ricardian model that relegates urban land use to a residual category. Doing so may seem innocuous in a region where the share of acreage in urban use is small. But inclusion of this land use in a residual category will arbitrarily set the rent accruing to urban land to zero when this rent is likely to be high. It also will restrict urban use to an arbitrary subset of land quality, and will omit variables (such as population and income) which intuition suggests are important determinants of land use.

These undesirable attributes motivate incorporation of the von Thünen location rent theory into the land share model. We do this by extracting a residential land area function from Capozza and Helsley's (1989) exposition of the location rent theory. Once obtained, the residential function is added to the rural land share model to create a model that 
explicitly incorporates urban and rural land uses.

Location rent theory postulates an urban area where employment and shopping is located in a central business district (CBD) and where commuting costs are important. The area is compact because commuting costs are positive. If housing is durable and not replaced, growth will occur at the rural-urban fringe when new housing is constructed to accommodate an expanding population. ${ }^{3}$ If land quality does not affect urban development, this boundary will expand in annular rings of $2 \eta$ radians as the number of households increases over time. In this case, the boundary of the urban area can be defined at time $t$ by its distance $z^{b}(t)$ from the CBD.

When everyone is housed, the area in residential use at time $t$ will equal the product of the average housing lot size $L$ and the number of households $N(t):^{4}$

$\eta z^{b}(t)^{2}=L N(t)$

Equilibrium rents within the boundary $z^{b}(t)$ at any distance $\mathrm{z}$ from the CBD will be:

$$
\begin{aligned}
R(t, z) & =\pi^{*}+\mathrm{pc}+(T / L)\left[z^{b}(t)-z\right] \\
z & \leq z^{b}(t),
\end{aligned}
$$

where $\mathrm{p}$ is a discount rate, $\mathrm{C}$ is the cost of converting a unit of land from rural to urban use, $T$ is a per-unit-distance commuting cost, and $\pi^{*}$ is the rent accruing to land outside the rural-urban boundary (Capozza and Helsley 1989, 299). ${ }^{5}$ Equation [5] shows the equilibrium rent for urban land to be the sum of the Ricardian rent for rural land, the "rent" on the capital used to convert rural land to residential use, and location or accessibility rent.

At the rural-urban boundary, location rent is zero, and

$R\left(t, z^{b}(t)\right)=\pi^{*}+\rho C$.

Urban rent will dominate rural rent inside this boundary since $\rho, \mathrm{C}, T$, and $L$ will all take positive values.

Equilibrium is determined in the location rent model by equating household demand for housing services to the supply of housing provided by landowners. Land is developed when the rent from residential use rises enough to offset the opportunity cost of rural land and conversion capital. Thus equation [6] also is the land conversion condition for Iandowners who maximize the present value of a site's stream of future rents (Capozza and Helsley 1989, 298).

The land area function is derived by solving the equilibrium rent function [5] for $\mathrm{z}$, using a household budget constraint to substitute $R$ out, and then using equation [4] to convert the resulting boundary relationship into an area relationship. Capozza and Helsley (1989) specify the household's budget constraint as

$Y=\mathrm{x}+R L+T z$

where $\mathrm{Y}$ is household income and $\mathrm{X}$ is a composite good representing consumption of all items other than housing. For equilibrium to be established, this constraint must apply at every point in time $t$ and location z. R. T, C, and $\pi^{*}$ also must be normalized so that the composite good has a unit price. Using this constraint, the land area that will be devoted to residential use when the market is in equilibrium is:

Area $=\frac{1}{T}\left[Y \quad X \quad L\left(\pi^{*}+\rho C\right)\right][\eta N(t) L]^{1 / 2}$.

Area in residential use thus becomes a function of commuting costs, household income, consumption of goods other than housing, level of housing consumption $(L)$, rural land rent, conversion costs, the discount rate, and population.

The term $L\left(\pi^{*}+\rho C\right)$ in [8] can be interpreted as the rental value of an average housing lot at the rural-urban fringe under the as-

'This durable housing assumption is relaxed in the Hrueckner (1980) and Wheaton (1982b) version of the theory.

4 Average lot size (L) is treated as exogenous, though the theory can be expanded to make it endogenous (Fajila 1982).

${ }^{5}$ We replace an exogenous constant A with $\pi^{*}$ in this equation taken from Capozza and Helsley (1989). 
sumption that the landowner also is the developer. Note that $L=1$ if $\pi^{*}$ and $C$ are per acre of farmland and the average housing lot is one acre.

Equation [8] can be converted into the share of land that is in residential use in a region of given size and added to the land share model [3]:

$$
\begin{aligned}
\varphi^{\prime}(Q) & =F_{j}(P, Q) \text { for } j=1, \ldots, J-2 \\
\varphi^{\prime-1} & =F_{j-1}\left(Y, N, X, T, L, \pi^{*}, \rho, C\right) \\
\varphi^{l} & =\mathrm{i}-\sum_{j=1}^{J-1} \varphi^{\prime} .
\end{aligned}
$$

Land use shares remain compact sets in this extended model with change occurring at the margins of these sets. Rural land use continues to span $\mathrm{Q}$, but over a land base that is reduced by the area in the dominant residential USC. Model [9] allows both rural and residential land uses to have positive rent, and removes the restriction on the quality of land uses for urban purposes. It introduces exogenous variables that should affect land use, but that are omitted from model [3].

The formulation also provides an opportunity for an empirical test of the prevailing practice of separating rural and urban land use analyses. Urban use is modeled as a dominant use whose share is mostly determined by an exogenous set of rent determinants. If rural landowners do separate production and development decisions, so that $\pi^{*}$ is not simultaneously determined, extending model (3) into model (9) should not significantly affect parameter estimates for the rural land share equations. Nor should parameter estimates vary much in an urban land share model which omits the simultaneous determination of rural land use shares. Thus the model, as formulated, offers a reasonable opportunity to test the empirical validity of the current analytical separation between urban and rural land use.

The application of this model is developed in the next section. Then results from the application are used to test the consequences of treating either rural or urban land as a resid- ual use. Elasticities obtained from the model are presented in the section after that.

\section{PREDICTING LAND USE IN THE SOUTH}

\section{Data and Methods}

Land use is categorized in the application as farm, forest, urban (also called "residential"), and other. Farm has been divided into crop and pasture subcategories in Hardie and Parks (1997), and Forest has been disaggregated into forest types in Alig (1986). Broader categories are used here because the rent determinants cannot be disaggregated, and we want to maintain the theoretical structure of the land share model as much as is possible. The urban category includes residences, commercial and industrial sites, airports, cemeteries, highways, institutional sites, public administration sites, and other infrastructure in built-up areas. It also includes strip development along roads if building density is one or more structures per 1.5 acres. Other is a residual category that includes federal and other public lands, waterways, rural infrastructure, and land not included in the farm, forest, and urban categories.

The land use categories are aggregations of categories defined in the National Resource Inventory (NRI) surveys. Estimates of land use shares are developed from these surveys for 1982, 1987, and 1992. The surveys provide some 633,500 point estimates from which to develop county-level land use share estimates. The minimum number of sample points used to construct a county estimate is 86. The maximum is 1,016 .

The NRI surveys also provide land quality data. Among these data are Land Capability Classes (LCC), which indicate the land's suitability for farming (USDA Soil Conservation Service 1961), and Major Land Resource Areas (MLRAs), which are general categories that incorporate topography, elevation, climate, soil type, and natural vegetation (USDA Soil Conservation Service 1981). The land capability variable used in this analysis is the proportion of land in each 
county in Land Capability Classes I and II. This is a measure of good farmland. MLRAs are represented by dummy variables that take the value of one whenever acreage in a MLRA also is in a county.

County-level estimates of farm product prices and costs are constructed from point sample data gathered during the 1982, 1987, and 1992 Censuses of Agriculture. Farm revenue estimates are divided by the number of acres of farmland in each county to create a composite-commodity agricultural product price. Per-acre farm expenditures are computed as summations of expenditures for feed, seed, fertilizer, agricultural chemicals, petroleum products, electricity, hired labor, custom work, and machinery-equipment. The 1987 and 1992 surveys also report expenditures on farm cash rents, interest, property taxes, machinery-equipment maintenance and repair, and "other" farm production items. These expenditures are omitted so 1982 observations can be included in the pooled data set.

Farmland owner estimates of the market value of farmland and buildings from the Censuses of Agriculture also were aggregated, and per-acre prices were constructed by dividing these estimates by the total farm acreage in the county. These prices are not capitalized farm use values, assessed values or sales values net of real estate marketing charges. They are estimates of the current total sales value of the land and buildings. We use these estimates as measures of the conversion value of the land at the rural-urban boundary (cf. equation [6]).

Sawtimber and pulpwood prices are developed from Timber Mart South data maintained at the U.S. Forest Service Southern Forest Experiment Station. Sawtimber prices are annual prices for southern yellow pine, measured in dollars per 1,000 board feet (mbf). Pulpwood prices are dollars per cord for softwood pulpwood.

Timber establishment costs are developed for each MLRA from data obtained from Tim Osborne of the USDA Economic Research Service. These cost estimates are constructed from cost share payments made for tree planting during the first 12 sign-ups of the Conservation Reserve Program.
County population and median house values are obtained for 1982, 1987, and 1992 from data produced by the U.S. Department of Commerce, Bureau of the Census. Estimated median household incomes are obtained for the same years from data provided by the U.S. Department of Commerce, Bureau of Economic Analysis. Consumption of items other than housing is indirectly represented in the empirical model by inclusion of both income and housing value variables. The hypothesis underlying this specification is that consumers in counties with relatively higher household incomes and lower housing values will consume relatively more of the composite commodity X. Since X has a negative sign in equation [8], this hypothesis leads us to expect a positive relationship between housing values and the proportion of land used for residential purposes. Conversion costs $\mathrm{C}$ also are implicitly represented in the model by including both housing and estimated farm sales values.

The estimated model omits measures of lot size and per-unit commuting costs. While these variables appear in the theoretical model, we could not find suitable measures for them in the cross section at the county level for the study's time period. Since lot size and transportation costs interact with all of the variables in the urban equation, their omission could affect all of the equation's parameter estimates. Since an exact specification of equation [8] is not possible, a second-order approximation (a generalized Leontief) is specified for the urban equation. It is important to note that elasticity estimates obtained from this approximation will implicitly incorporate lot size and transportation cost effects. Predictions based on these elasticities will be suitable only if these implicit effects do not change.

Dummy variables representing the states are included in the urban equation to allow for differences in state-level expenditures for transportation infrastructure and for differences in state-level programs that may affect lot size. While this should remove some of the omitted variable effects, it will not remove all specification error from the model's error structure. Amemiya and Nold (1975) cite omitted variables as justification for their 
TABLE 1

VARIABLES USED IN THE ANALYSIS

\begin{tabular}{|c|c|c|c|}
\hline Variable & Description & Mean & Std. Dev. \\
\hline Year82 & I if 1982 ; zero otherwise & 0.29 & \\
\hline Year87 & 1 if 1987 ; Zero otherwise & 0.32 & \\
\hline Year92 & 1 if 1992 ; zero otherwise & 0.39 & \\
\hline Acres & Total land area (acres) & 342,674 & 165,273 \\
\hline Farm & Share of total land area in farming & 0.32 & 0.19 \\
\hline Forest & Share of total land area in forest & 0.49 & 0.20 \\
\hline Urban & Share of total land area in residential use & 0.046 & 0.067 \\
\hline Mktagac & Farm product revenues/farm acres (\$/acre) & 228 & 242 \\
\hline Expac82 & Farm expenditures-1982 items (\$/acre) & 113 & 131 \\
\hline Timbcost & Timber establishment cost (\$/acre) & 95 & 28 \\
\hline Siprice & Southern yellow pine sawtimber price $(\$ / \mathrm{mbf})$ & 149 & 71 \\
\hline Pworice & Softwood pulpwood price (\$/cord) & 15 & 8 \\
\hline Plor2 & Proportion of land in LCC 1 or 2 & 0.22 & 0.15 \\
\hline Ponulat & Population & 54,292 & 143,011 \\
\hline Houseval & Median house value $(1,000 \$)$ & 44.71 & 17.15 \\
\hline Houseinc & Median household income $(1,000 \$)$ & 20.61 & 6.54 \\
\hline Estfval & Farm real estate value (\$/acre) & 1,126 & 645 \\
\hline
\end{tabular}

modification of the binomial logit model. This motivated us to use an iterated version of their method to estimate parameters for an urban model based on equation [8]. We also use an iterated version of Park's (1980) multinomial extension of the Amemiya-Nold procedure (Hardie and Parks 1997) to obtain parameter estimates for a rural model based on [3] and a rural-urban model based on [9].

Table 1 gives a summary description of the data assembled for the analysis. Parameter estimates for the land use equations are reported in Tables 2-4. Parameter estimates corresponding to the MLRA and State dummy variables are omitted to keep the presentation from becoming unwieldy.

\section{Estimation Results}

Table 2 gives parameter estimates for the urban land share equations obtained from the rural-urban and urban models. $F$ and Wald tests indicate that both models have jointly significant parameter estimates (cf. Table 5). McElroy's System R-squared is 0.468 for the rural-urban model, lower than the R-squared of 0.648 obtained for the binomial urban model. All parameter estimates in Table 2 are different from zero at the 5\% significance level except for those associated with the variable Estfval. Fann land values are part of other significant terms in the model, however, and marginal values obtained from the model for Estfval are significant. Thus the hypothesis that rural land values can be treated as exogenous constants is not necessarily supported by the empirical results in Table 2.

As elasticities derived from these estimates will show, signs for the parameter estimates of the models continuous variables are as expected. In addition, most of the State dummy variables have significant parameter estimates at the 5\% level.

Inspection of Table 2 shows generally similar parameter estimates for the ruralurban and urban models. Thus the possibility remains that urban land use can be analyzed without having to introduce the rural land uses.

We estimated models containing Generalized Leontief specifications for the continuous variables in the forest and farm equations but did not find them to be better than the linear specifications reported in Tables 3 and 4. We also estimated models that included all farm and forest prices and costs in each rural equation. The added variables did not significantly improve the models' ability to predict the log-odds of the land use shares. Our exploration did find that pulpwood and sawtimber prices acted as collinear variables in 
TABLE 2

URRAN LAND USE EOUATIONS

\begin{tabular}{|c|c|c|c|c|}
\hline \multirow[b]{2}{*}{ Variable } & \multicolumn{2}{|c|}{ Rural-Urban $\quad$ Model" } & \multicolumn{2}{|c|}{ Urban Model ${ }^{\mathrm{b}}$} \\
\hline & $\begin{array}{c}\text { Parameter } \\
\text { Estimate }\end{array}$ & $\begin{array}{l}\text { Std. Error } \\
\text { of Estimate }\end{array}$ & $\begin{array}{c}\text { Parameter } \\
\text { Estimate }\end{array}$ & $\begin{array}{l}\text { Std. Error } \\
\text { of Estimate }\end{array}$ \\
\hline Year82 & $-2.543 * *$ & 0.0875 & $-4.929 * *$ & 0.08878 \\
\hline Year87 & $-2.770^{* *}$ & 0.1003 & $-4.988^{* *}$ & 0.1036 \\
\hline Year92 & $-2.948 * *$ & 0.1157 & $-4.991 * *$ & 0.1210 \\
\hline Popden ${ }^{c}$ & $-0.003454 * *$ & 0.000333 & $-0.004151 * *$ & 0.000381 \\
\hline Houseinc & $-0.3507^{* *}$ & 0.09578 & $-0.2637^{*}$ & 0.1049 \\
\hline Houseval & $-0.1724 * *$ & 0.04432 & $-0.1161^{*}$ & 0.04942 \\
\hline Estfval & -0.000526 & 0.000297 & -0.000386 & 0.000334 \\
\hline (Popden*Houseinc) $^{1 / 2}$ & $0.08618^{* *}$ & 0.008681 & $0.1271 * *$ & 0.009904 \\
\hline (Popden*Houseval) $^{1 / 2}$ & $-0.03647^{* *}$ & 0.006011 & $-0.0532^{* *}$ & 0.006917 \\
\hline (Popden*Esifval) & $0.002117 * *$ & 0.000550 & 0.001210 & 0.000624 \\
\hline (Houseinc*Houseval) ${ }^{1 / 2}$ & $0.5096^{* *}$ & 0.1266 & $0.3422^{*}$ & 0.1397 \\
\hline (Houseinc*Estfval) $^{1 / 2}$ & $-0.01950^{* *}$ & 0.007563 & $-0.0254 * *$ & 0.008489 \\
\hline (Houseval*Estfval) ${ }^{1 / 2}$ & $0.01357^{*}$ & 0.006140 & $0.01809^{* *}$ & 0.006936 \\
\hline
\end{tabular}

Notes: Estimates are not reported for 11 State dummy variables.

${ }^{2} \mathrm{R}^{2}$ for the equation is 0.436 .

${ }^{6} \mathrm{R}^{2}$ for the equation is 0.649 .

'Popden $=$ Population per square mile.

* Significant at $5 \%$; ${ }^{*}$ significant at $1 \%$.

the forest land equation. Models with sawtimber price are presented in Table 4 because they have more degrees of freedom $(2,298$ observations instead of 2,233).

\section{Elasticities}

Interpretation of the parameter estimates reported in Tables 2-4 is complicated both by the log-odds transformation of the dependent variables and by the nonlinear specification of the urban equation. To assist inter- pretation, we extracted marginal changes in land shares from the parameter estimates (Greene 1990, 697-701), and then computed partial elasticities at the means of the untransformed continuous variables. Elasticities are computed only if the marginal values are significantly different from zero at the $5 \%$ significance level. These elasticity estimates are reported in Table 5. They give the percentage change in a land use share that would result from a one percent change in an explanatory variable, other explanatory vari-

TABLE 3

FARM LAND USE EQUATIONS

\begin{tabular}{lccccc}
\hline \hline & \multicolumn{2}{c}{ Rural-Urban } & Model” & & \multicolumn{2}{c}{ Rural $^{\text {Model }}$} \\
\cline { 2 - 3 } \cline { 5 - 6 } Variable & $\begin{array}{c}\text { Parameter } \\
\text { Estimate }\end{array}$ & $\begin{array}{c}\text { Std. Error } \\
\text { of Estimate }\end{array}$ & & $\begin{array}{c}\text { Parameter } \\
\text { Estimate }\end{array}$ & $\begin{array}{c}\text { Std. Error } \\
\text { of Estimate }\end{array}$ \\
\hline Year82 & $-0.3121^{*}$ & 0.1393 & & $-0.5929^{* *}$ & 0.1552 \\
Ycar87 & $-0.4552^{* *}$ & 0.1385 & & $-0.7483^{* *}$ & 0.1545 \\
Year92 & $-0.6105^{* *}$ & 0.1374 & & $-0.9276^{* *}$ & 0.1536 \\
Mktagac & $0.001508^{* *}$ & 0.000335 & & $0.001682^{* *}$ & 0.000347 \\
Expac82 & $-0.002335^{* *}$ & 0.000626 & & $-0.002741^{* *}$ & 0.000648 \\
Timbcost & $0.006949^{* *}$ & 0.001406 & & $0.005526^{* *}$ & 0.001592 \\
PI or2 & $2.932^{* *}$ & 0.1280 & & $3.514^{* *}$ & 0.1461 \\
\hline
\end{tabular}

Notes: Estimates are not reported for 35 MLRA dummy variables.

$\mathrm{R}^{2}$ for the equation is 0.390 .

$\mathrm{R}^{2}$ for the equation is 0.419 .

* Significant at 5 percent. ${ }^{* *}$ significant at 1 percent 
TABLE 4

Forest LAND Use Equations

\begin{tabular}{|c|c|c|c|c|}
\hline \multirow[b]{2}{*}{ Variable } & \multicolumn{2}{|c|}{ Rural-Urban Model" } & \multicolumn{2}{|c|}{ Rural Model ${ }^{b}$} \\
\hline & $\begin{array}{l}\text { Parameter } \\
\text { Estimate }\end{array}$ & $\begin{array}{l}\text { Std. Error } \\
\text { of Estimate }\end{array}$ & $\begin{array}{l}\text { Parameter } \\
\text { Estimate }\end{array}$ & $\begin{array}{l}\text { Std. Error } \\
\text { of Estimate }\end{array}$ \\
\hline Year82 & $1.850^{* *}$ & 0.1635 & $1.586^{* *}$ & 0.1836 \\
\hline Year87 & $1.802^{* *}$ & 0.1604 & $1.523^{* *}$ & 0.1806 \\
\hline Year92 & $1.388^{* * *}$ & 0.1868 & $1.098^{* *}$ & 0.2071 \\
\hline Stprice & $0.002647^{* *}$ & 0.000435 & $0.002510^{* *}$ & 0.000454 \\
\hline Timhcost & $-0.005637 * *$ & 0.001465 & $-0.00710^{* *}$ & 0.001689 \\
\hline P l or2 & -0.01278 & 0.1285 & $0.5710^{* *}$ & 0.1497 \\
\hline
\end{tabular}

Notes: Estimates are not reported for 35 MLRA dummy variables

${ }^{2} R^{2}$ for the equation is 0.348 .

${ }^{b} \mathrm{R}^{2}$ for the equation is 0.363 .

** Significant at $1 \%$.

ables held constant. As noted earlier, lot size and transportation cost are not held constant, and these elasticities have limited usefulness for predictive purposes.

Table 5 shows the urban share of land to be an increasing function of population, median household income, and median house value. Urban land shares decrease with increases in the estimated per-acre value of farmland and buildings. All responses are inelastic, and that for farm land values is particularly small. In general, elasticities increase in magnitude when the model is extended to include both urban and rural land uses.

Farm and forest land use shares are found to increase with output prices and to decrease with production costs. These responses are all inelastic. The positive response of the farm land share to an increase in the costs of pro-

TABLE 5

elasticity estimates at means of PoOled OBSERVATIONS

\begin{tabular}{llcrr}
\hline \hline $\begin{array}{l}\text { Land } \\
\text { Affected }\end{array}$ & $\begin{array}{l}\text { Exogenous } \\
\text { Change in }\end{array}$ & $\begin{array}{c}\text { Rural-Urban } \\
\text { Model }\end{array}$ & $\begin{array}{c}\text { Urban } \\
\text { Model }\end{array}$ & $\begin{array}{c}\text { Rural } \\
\text { Model }\end{array}$ \\
\hline Urban & Populat & 0.46 & 0.47 & \\
Urban & Houseinc & 0.61 & 0.37 & \\
Urban & Houseval & 0.20 & 0.13 & \\
Urban & Estfval & -0.12 & -0.07 & \\
Farm & Mktagac & 0.23 & & 0.26 \\
Farm & Expac82 & --0.18 & & -0.21 \\
Farm & Timbcost & 0.73 & & 0.69 \\
Farm & Plor2 & 0.44 & & 0.45 \\
Forest & Stprice & 0.20 & & 0.19 \\
Forest & Timhcost & -0.50 & & -0.53 \\
Forest & Plor2 & --0.22 & & -0.19 \\
\hline
\end{tabular}

ducing timber is consistent with the hypothesis that forest and farm production are competing land uses. Elasticities for the land quality variable in Table 5 indicate that counties with higher proportions of good farmland have greater proportions of land in farming, and correspondingly smaller shares of forest land. Other factors are held constant in the estimation of these elasticities, however, and higher timber net returns or lower farm net returns may offset this partial land use effect.

No particular pattern emerges when one compares the magnitudes of elasticities across models. Instead the dominant impression is that the elasticities are reasonably close in size. This suggests that estimation of rural land use models that relegate urban land uses to a residual category may be a useful simplification, and that it may not be necessary to integrate the Ricardian and location rent hypotheses. We now turn to some more formal tests of that hypothesis.

\section{CAN RURAL OR URBAN BE TREATED AS RESIDUAL LAND USES?}

Omitting the residential land share equation from the rural-urban system removes 24 variables and omitting the farm and forest equations removes 83 variables. Change in the parameter estimates for the continuous variables is relatively small when one considers the number of variables omitted, suggesting that the use of restricted models may be reasonable in cases where data is difficult 
TABLE 6

Results OF Model Hypothesis Tests

\begin{tabular}{|c|c|c|}
\hline Hypothesis & F Statistic & $\begin{array}{r}\text { Wald } \\
\text { Statistic }\end{array}$ \\
\hline $\begin{array}{l}\text { Parameter estimates for the urban equation of the rural-urban } \\
\text { model are not different from zero }\end{array}$ & $164.7 * *$ & $3459.5 * *$ \\
\hline $\begin{array}{l}\text { Parameter estimates for the rural equations of the rural-urban } \\
\text { model are not different from zero }\end{array}$ & $52.4 * *$ & $4033.3 * *$ \\
\hline $\begin{array}{l}\text { Parameter estimates for the urban equation are the same in } \\
\text { the rural-urban and urban models }\end{array}$ & $5.0^{* *}$ & $106.0 * *$ \\
\hline $\begin{array}{l}\text { Parameter estimates for the rural equations are the same in } \\
\text { the rural-urban and rural models }\end{array}$ & $2.2 * *$ & $167.0^{* *}$ \\
\hline $\begin{array}{l}\text { Continuous variable parameter estimates for the urban equa- } \\
\text { tion are the same in the rural-urhan and urban models }\end{array}$ & $5.3^{* *}$ & $53.4^{* *}$ \\
\hline $\begin{array}{l}\text { Continuous variable parameter estimates for the rural equa- } \\
\text { tions arc the same in the rural-urban and rural models }\end{array}$ & $4.8^{* *}$ & $33.7 * *$ \\
\hline
\end{tabular}

to obtain. This is particularly true of the standard errors of estimates, which increase only marginally in the restricted model cases. It should be noted, however, that the estimates for the MLKA and State dummy variables change more than those for the continuous variables when equations are omitted from the rural-urban model.

More formal tests lead to rejection of the hypothesis that rural and urban land uses can be treated separately. We tested three hypotheses about the rural-urban model: (1) that the parameter estimates corresponding to the omitted equations are, as a group, insignificantly different from zero; (2) that the estimates obtained from the rural-urban model are, as a group, insignificantly different from the corresponding estimates obtained from the restricted models, and (3) that the subset of parameter estimates obtained for the continuous variables from the integrated model are insignificantly different from those obtained from the separate models. These tests were conducted using $\mathrm{F}$ and Wald statistics (Greene 1990, 5 14), since the iterated modified multinomial logit model is a feasible generalized least squares model. Computed statistics for these tests of hypotheses are given in Table 6 .

As the table shows, all of the null hypotheses are rejected at the $1 \%$ level of significance. Thus the impression that little is gained by integrating the rural and urban models is not borne out by the formal hypothesis tests.

\section{LAND USE RESPONSE IN RURAL AND URBAN COUNTIES}

Investigation of county population densities indicates that the South encompasses very rural and very urban counties. Table 7

TABLE 7

Population Densities and land Use Shares: Means of Selected Population Quantiles

\begin{tabular}{|c|c|c|c|c|c|c|c|c|c|c|c|c|}
\hline \multirow[b]{2}{*}{ Quantile } & \multicolumn{3}{|c|}{$\begin{array}{c}\text { People Per Square } \\
\text { Mile }\end{array}$} & \multicolumn{3}{|c|}{$\begin{array}{l}\text { Percentage of Urban } \\
\text { L and }\end{array}$} & \multicolumn{3}{|c|}{$\begin{array}{c}\text { Percentage of } \\
\text { Farmland } \\
\end{array}$} & \multicolumn{2}{|c|}{ Percentage } & \multirow{2}{*}{$\begin{array}{r}\text { Forest } \\
1992\end{array}$} \\
\hline & 1982 & 1987 & 1992 & 1982 & 1987 & 1992 & 1982 & 1987 & 1992 & 1982 & 1987 & \\
\hline $5^{\text {th }}$ Percentile & 13 & 14 & 13 & 0.5 & 0.6 & 0.7 & 23 & 21 & 23 & 60 & 61 & 60 \\
\hline I"' Quartile & 22 & 22 & 23 & 1.0 & 1.1 & 1.3 & 27 & 25 & 26 & 59 & 61 & 58 \\
\hline $2^{\text {nd }}$ Quartile & 38 & 38 & 40 & 1.6 & 1.9 & 2.4 & 37 & 35 & 33 & 50 & 51 & 50 \\
\hline $3^{\text {rd }}$ Quartile & 63 & 64 & 70 & 3.0 & 3.4 & 4.2 & 39 & 38 & 34 & 46 & 45 & 47 \\
\hline $4^{\text {th }}$ Quartile & 255 & 282 & 280 & 10.0 & 11.4 & 13.4 & 34 & 33 & 29 & 41 & 40 & 43 \\
\hline $95^{\text {th }}$ Percentile & 703 & 804 & 752 & 22.2 & 26.0 & 29.0 & 29 & 26 & 21 & 32 & 27 & 34 \\
\hline
\end{tabular}


TABLE 8

Elasticity of Urban Land use at Means of Selected Population Quantiles

\begin{tabular}{|c|c|c|c|c|c|c|c|c|c|c|c|c|}
\hline \multirow[b]{2}{*}{ Quantile } & \multicolumn{3}{|c|}{$\begin{array}{l}\text { Change in } \\
\text { Population }\end{array}$} & \multicolumn{3}{|c|}{$\begin{array}{l}\text { Change in Median } \\
\text { Household Income }\end{array}$} & \multicolumn{3}{|c|}{$\begin{array}{l}\text { Change in Median } \\
\text { House Value }\end{array}$} & \multicolumn{3}{|c|}{$\begin{array}{c}\text { Change in Estimated } \\
\text { Farm Value }\end{array}$} \\
\hline & 1982 & 1987 & 1992 & 1982 & 1987 & 1992 & 1982 & $19 \times 7$ & 1992 & $19 \times 2$ & 1987 & 1992 \\
\hline $5^{\text {th }}$ Percentile & 1.50 & 1.47 & 1.32 & -1.02 & -1.20 & -1.26 & 3.90 & 4. 19 & 4. 16 & -1.49 & -1.32 & 1. 26 \\
\hline $\begin{array}{l}\text { 1" Quartile } \\
2^{\text {nd }} \quad \text { Quartile }\end{array}$ & $\begin{array}{l}0.98 \\
0.80\end{array}$ & $\begin{array}{l}1.02 \\
0.74\end{array}$ & $\begin{array}{l}0.99 \\
0.71\end{array}$ & $\begin{array}{r}-0.08 \\
0.37\end{array}$ & $\begin{array}{r}-0.13 \\
0.37\end{array}$ & $\begin{array}{r}-0.34 \\
\mathbf{0 . 1 9}\end{array}$ & $\begin{array}{l}1.85 \\
1.01\end{array}$ & $\begin{array}{l}2.09 \\
1.00\end{array}$ & $\begin{array}{l}2.28 \\
1.12\end{array}$ & $\begin{array}{l}-0.77 \\
-0.46\end{array}$ & $\begin{array}{l}-0.67 \\
-0.36\end{array}$ & $\begin{array}{l}-0.71 \\
-0.39\end{array}$ \\
\hline $3^{\text {td }}$ Quartile & 0.53 & 0.53 & 0.51 & 0.57 & 0.64 & 0.50 & 0.35 & 0.34 & 0.44 & -0.21 & -0.17 & -.0 .20 \\
\hline 4"' Quantile & 0.24 & 0.25 & 0.27 & 0.60 & 0.65 & 0.57 & -0.13 & -0.14 & -0.06 & -0.01 & 0.00 & -0.02 \\
\hline $95^{\text {th }}$ Percentile & 0.08 & 0.09 & 0.13 & 0.54 & 0.57 & 0.53 & -0.23 & -0.23 & -0.19 & 0.05 & 0.05 & 0.03 \\
\hline
\end{tabular}

shows that densities in the region range from averages of 13- 14 people per square mile (one person per 35 acres) to $700-800$ people per square mile (one person per two-thirds of an acre). These averages are for counties in the lowest and highest 5\% of the ordered density data. They include 33 counties for 1982, 36 for 1987, and 45 for 1992.

Table 7 also gives the average percentage of urban, farm, and forest land in counties with different population densities. As can be seen, urban land share increases with population density from less than a percent to $25 \%$ or more of the county land base. Farmland share increases from $20-23 \%$ of the land in the very rural counties to $33-39 \%$ of the land in counties with population densities in the middle quartiles. This share then decreases to $29 \%$ of the area of the very urban counties in 1982 , and to $21 \%$ in 1992 .

While farmland share rises and then falls with increasing population density, the share of forest decreases steadily from $60 \%$ to $30 \%$. The table also provides some evidence that urban land use is increasing and that farming is decreasing over time in the region, with most of this change occurring in the higher density counties.

The substantial range of population density offers an opportunity to investigate how land use responds to changes in land use determinants in counties with different degrees of urbanization. This is done in Tables $8-10$, which give land share response elasticities computed at the means of land use determinants for observations in different quantiles of population densities. Table 8 presents elasticities for urban land use shares, Table 9 presents farmland share response elasticities, and Table 10 presents elasticities showing how the share of land in forest responds to change in sawtimber stumpage prices and timber plantation establishment costs.

The variation observed in these elasticity estimates results from differences in the levels of land use shares and land use determinants across quantiles and time periods. Marginal values used to calculate the slope coefficients of the elasticities are the same

TABLE 9

Elasticity of Farmland Use at Means of Selected Population Quantiles

\begin{tabular}{|c|c|c|c|c|c|c|c|c|c|}
\hline \multirow[b]{2}{*}{ Quantile } & \multicolumn{3}{|c|}{ Change in Farm Revenue } & \multirow{2}{*}{$\begin{array}{l}\text { Change } \\
1982\end{array}$} & \multirow{2}{*}{$\begin{array}{r}\text { Farm } \\
1987\end{array}$} & \multirow{2}{*}{$\begin{array}{r}\text { Expenditure } \\
1992\end{array}$} & \multicolumn{3}{|c|}{$\begin{array}{l}\text { Change in Timber } \\
\text { Establishment Cost }\end{array}$} \\
\hline & 1982 & 1987 & 1992 & & & & 1982 & 1987 & 1992 \\
\hline $\begin{array}{ll}5^{\text {th }} & \text { Percentile } \\
1^{\text {st }} & \text { Quartile }\end{array}$ & $\begin{array}{l}0.15 \\
0.16\end{array}$ & $\begin{array}{l}0.24 \\
0.23\end{array}$ & $\begin{array}{l}0.27 \\
0.28\end{array}$ & $\begin{array}{l}-0.12 \\
-0.13\end{array}$ & $\begin{array}{l}-0.18 \\
-0.18\end{array}$ & $\begin{array}{l}-0.21 \\
-0.22\end{array}$ & $\begin{array}{l}1.05 \\
0.84\end{array}$ & $\begin{array}{l}1.09 \\
0.90\end{array}$ & $\begin{array}{l}1.04 \\
0.87\end{array}$ \\
\hline $2^{\text {nd }}$ Quartile & 0.15 & 0.17 & 0.26 & $=0.11$ & -0.13 & -0.20 & 0.65 & 0.61 & 0.70 \\
\hline $3^{\text {td }}$ Quartile & 0.15 & 0.17 & 0.29 & -0.11 & -0.13 & -0.22 & 0.64 & 0.64 & 0.69 \\
\hline $4^{\text {th }}$ Quartile & 0.21 & 0.28 & 0.38 & -0.15 & -0.22 & -0.29 & 0.72 & 0.73 & 0.78 \\
\hline $95^{\text {th }}$ Percentile & 0.31 & 0.47 & 0.50 & -0.22 & -0.36 & -0.37 & 0.88 & 0.95 & 1.09 \\
\hline
\end{tabular}


T A B LE 10

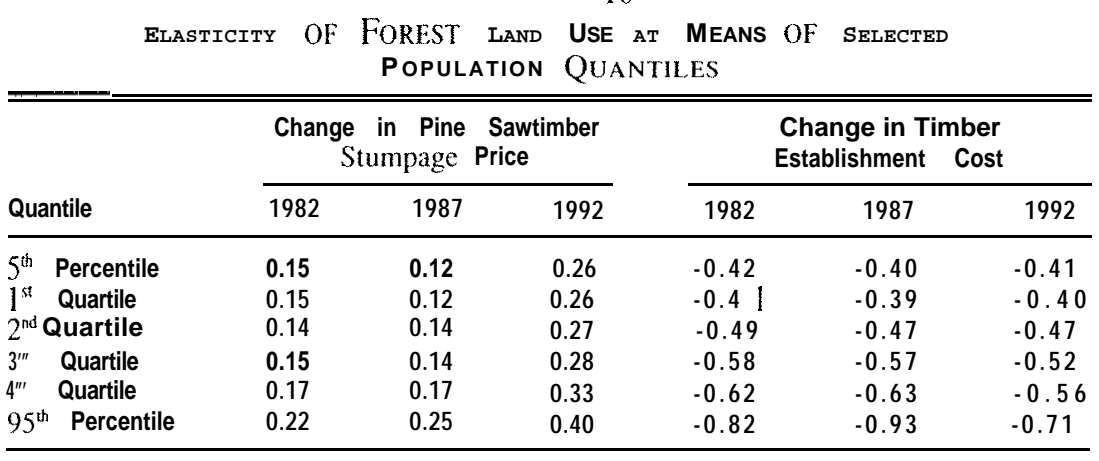

across years and across quantiles. These slope estimates are obtained from the nuralurban model. Elasticities are computed at quantile means instead of observed values for individual counties because of the sample error inherent in the county census data.

Urban land use in the very rural counties is most responsive to changes in population (or population density, since the elasticities are the same). Response is inelastic in quantiles with higher average population densities, and very inelastic in the very urban counties.

While urban land use always increases with population, it sometimes decreases with increases in median household income. This inverse relationship occurs only in sparsely populated counties. Elasticities are in the OS-o.65 range in counties with higher population densities.

Urban land shares decrease in urban counties when median house values increase. They increase and are elastic in the more rural half of the counties. Thus, more expensive housing is associated with more land in the rural counties and with less land in the urban counties. This may be due to higher location rents surrounding urban centers.

Urban land share essentially does not change when farm real estate values change in counties in the fourth quartile (which includes the 95" percentile). Signs change but elasticities are so close to zero that this land use response is negligible. Urban land use shares tend to be smaller in rural counties when farm real estate values are higher. This relationship becomes elastic in the most sparsely populated counties, where farm quasi-rents are a large component of urban rents. Elasticities seem to be decreasing over time in these very rural counties, but this temporal trend is not evident in counties with higher population densities.

Farmland shares increase with increases in farm revenues. They decrease with increases in farm expenditures. Table 9 suggests these responses are becoming more elastic over time, although all of the measured elasticities remain 0.5 or less in magnitude. The Ricardian rent model offers no particular explanation for this phenomenon, as it is static in nature. Elasticity of farmland share with respect to the cost of establishing timber plantations is positive, an expected result in a region in which timber and agriculture are substitutes in production.

As also would be expected, forest land share responds positively to increases in pine stumpage prices and negatively to increases in timber production costs. These responses are all inelastic, and are less for price changes than for cost changes. Elasticities with respect to price are higher in 1992, but this may be an anomaly since these elasticities show no trend over time. Responses also tend to be higher in highly urban counties, perhaps because of more active change at the urban-forest land use margin.

\section{CONCLUSION}

Despite the significant simplification inherent in the underlying land rent models, the estimated land share models have good sta- 
tistical validity. Marginal effects derived from the models are statistically significant and of expected sign. When measured at the overall data means, percentage changes in land shares are less than those of land rent determinants. Considerable differences are hidden within these inelastic aggregate responses, however, as elasticities of land use vary substantially in magnitude and sometimes change sign when counties are grouped according to population density. Such results add support to Bockstael's and h-win's (1999) observation about the intended and unintended effects of public policies. From our findings, one can draw few universal conclusions about the response of land use to change in the determinants of land rent.

Our tests of model specification indicate that the rural-urban model provides significantly different parameter estimates from the rural and urban models. This finding gains additional cogency when it is noted that the rural and urban models produce reasonable results. These partial models could easily be accepted as empirically valid, even though the effects of omitting either rural or urban land use are significant.

Ricardian and von Thiinen rent theories combine easily into a single land share model when land use change is restricted to margins between land uses. Plantinga (1996) has explored some of the econometric implications of relaxing this margins restriction, but the cost of asserting that all land use change will be at such margins is not yet assessed.

Elasticity estimates from the rural-urban model show how much land use has responded to change in population, income, real estate values, prices, and costs, and how much these responses have differed across counties with different degrees of urbanization. Such estimates let one see why uniform policies have different results in different localities, and why targeted policies can be more efficient in inducing land use change. Predictions of where new policies will affect land use are circumscribed, however, by the inability to control for lot size and commuting costs. If land zoning were to change significantly or major new highways were to be built, predictions based on these elasticities would be suspect.

\section{References}

Adams, R. M., D. M. Adams, J. M. Callaway, C. C. Chang, and B. A. McCarl. 1993. "Sequestering Carbon on Agricultural Land: Social Cost and Impacts on Timber Markets." Contemporary Policy Issues I I (Jan.): 76-87.

Alig R. J. 1986. "Econometric Analysis of the Factors Influencing Forest Acreage Trends." Forest Science 32 (Mar.): I 19-34.

Alig, R. J., D. Adams, and B. A. McCarl 1998. "Impacts of Incorporating Land Exchanges Between Forestry and Agriculture in Sector Models." Journal of Agricultural and Applied Economics 30 (Dec.): 389-401.

Alonso, A. 1964. Location and Land Use. Cambridge: Harvard University Press.

Amemiya, T., and F. Nold. 1975. "A Modified Logit Model." Review of Economics and Statistics 55 (May): 255-57.

Anas, A. 1978. "Dynamics of Urban Residential Growth." Journal of Urban Economics 5:6687.

Arnott, R. J. 1980. "A Simple Urban Growth Model with Durable Housing." Regional Science and Urban Economics 10:53-76.

Babcock, B. A. 1990. "Acreage Decisions Under Marketing Quotas and Yield Uncertainty." American Journal of "Agricultural Economics 72 (Nov.): 958-65.

Bockstael, N. E. 1996. "Modeling Economics and Ecology: The Importance of a Spatial Perspective." American Journal of Agricultural Economics 78 (Dec.): 1 168-80.

Bockstael, N. E., and E. G. Irwin 1999. "Economics and the Land Use-Environment Link." Agricultural and Resource Economics, University of Maryland. Working Paper 99-04.

Bradshaw, 'T. K., and B. Muller. 1998. "Impacts of Rapid Urban Growth on Farmland Conversion: Application of New Regional Land use Policy Models and Geographic Infonnation Systems." Rural Sociology 63 (1): I-25.

Brandt, J. A.. J R. Kruse, and J. Todd. 1992. "Supply, Demand, and Effects of Alternative Policies on the U.S. Oats Industry." American Journal of Agricultural Economics 74 (May): 318-28.

Brueckner, J. K. 1980. "A Vintage Model of Urban Growth." Journal of Urban Economics 8: 389-402.

Capozza, D. R., and R. W. Helsley. 1989. "The Fundamentals of Land Prices and Urban Growth." Joumal of Urban Economics 26: 295-306.

Caswell, M., and D. Zilberman. 1985. "The Choice of Irrigation Technologies in Califor- 
nia." American Journal of Agricultural Economics 67 (May): 224-34.

Chang, C. C., B. A. McCarl, J. W. Mjelde, and J. W. Richardson. 1992. "Sectoral Implications of Farm Program Modifications." American Journal of Agricultural Economics 74 (Feb.): 38-49.

Chavas, J.-P., R. D. Pope, and R. S. Kao. 1983. "An Analysis of the Role of Futures Prices, Cash Prices and Government Programs in Acreage Response." Western Journal of Agricultural Economics 8 (July): 27-33.

Chavas, J.-P., and M. T. Holt. 1990. "Acreage Decisions Under Risk: The Case of Corn and Soybeans." American Journal of Agricultural Economics 72 (Aug.): 529-38.

Claassen, R., and A. Tegene 1999. "Agricultural Land Use Choice: A Discrete Choice Approach." Agricultural and Resource Economics Review 28 (Apr.): 26-36.

Fajita, M. 1982. "Spatial Patterns of Residential Development.' 'Journal of Urban Economics $12: 22-52$.

Gallagher, P. 1978. "The Effectiveness of Price Support Policy-Some Evidence for U.S. Corn Acreage Response." Agricultural Economics Research 30 (Oct.): 8-14.

Gardner, B. L. 1976. "Futures Prices in Supply Analysis." American Journal of Agricultural Economics 58 (Feb.): 81-84.

Greene, W. H. 1990. Econometric Analysis. New York: Macmillan Publishing Co.

Hardie, 1. W., and P. J. Parks. 1997. "Land Use with Heterogeneous Land Quality: An Application of an Area Base Model." American Journal of Agricultural Economics 79 (May): 299-3 10

Houck, J. P., M. E. Abel, M. E. Ryan, P. W. Gallagher, R. G. Hoffman, and J. B. Penn. 1976. "Analyzing The Impact of Government Programs On Crop Acreage." USDA Economic Research Service Technical Bulletin 1548. Washington D.C.: U.S. Government Printing Office.

Landis, J. 1995. "Imagining Land Use Futures: Applying the California Urban Futures Model." Journal of the American Planning Association 61 (4): 438-57.

Lee, D. R., and P. G. Helmberger. 198.5. "Estimating Supply Response in the Presence of Farm Programs." American Journal of $\mathrm{Ag}$ ricultural Economics 67 (May): 193-203.

Lichtenberg, E. R. 1985. "The Role of Land Quality in Agricultural Diversification." Ph.D. diss., University of California, Berkeley.

-1 1989. "Land Quality, Irrigation Development, and Cropping Patterns in the Northern
High Plains." American Journal of Agricultural Economics 71 (Feb.): 187-201.

Lidman. R., and D. L. Bawden. t 974. "The Impact of Government Programs on Wheat Acreage." Land Economics 50 (Nov.): 327-35.

McIntosh, C. S., and K. H. Shideed. 1989. "The Effect of Government Programs on Acreage Response Over Time: The Case of Corn Production in Iowa." Western Journal of Agricultural Economics 14 (July): 38-44.

Miller, D. J., and A. J. Plantinga 1999. "Modeling Land Use Decisions with Aggregate Data." American Journal of Agricultural Economics 81 (Feb.): 180-94.

Mills, E. S. 1967. "An Aggregative Model of Resource Allocation in a Metropolitan Area." American Economic Review 57 (May): 197. 210.

Miranda, M. J., F. Novak, and M. Lerohl. 1994. "Acreage Response Under Canada's Western Grains Stabilization Program." American Journal of Agricultural Economics 76 (May): $270-76$

Morzuch, B. J., R. D. Weaver, and P. G. Helmberger. 1980. "Wheat Acreage Supply Response under Changing Farm Programs." American Journal of Agricultural Economics 62 (Feb.): 29-37.

Muth, R. 1967. Cities and Housing. Chicago: University of Chicago Press.

Palmquist, R .B. 1989. "Land as a Differentiated Factor of Production: A Hedonic Model and Its Implications for Welfare Measurement." Land Economics 65 (Feb.): 23-28.

Parks, P.J., and B. C. Murray. 1994. "Land Attributes and Land Allocation: Nonindustrial Forest Use in the Pacific Northwest." Forest SCience 40 (Aug.): 558-75

Parks, R. W. 1980. "On the Estimation of Multinomial Logit Models from Relative Frequency Data." Journal of Economics 13 (Aug.): 293-303.

Plantinga, A.J. 1996. "The Effect of Agricultural Policies on Land Use and Environmental Quality." American Journal of Agricultural Economics 78 (Nov.): 1082-9 1 .

Shideed, K. H.. F. C. White, and S. J. Brannen. 1987. "The Responsiveness of U.S. Corn and Soybean Acreages to Conditional Price Expectations: An Application to the 1985 Farm Bill." Southern Journal of Agricultural Economics 19 (Dec.): 153-61.

Shonkwiler, J. S., and G. S. Maddala. 1985. "Modeling Expectations of Bounded Prices: An Application to the Market for Corn." Review of Economics and Statistics 67 (Nov.): 697-702. 
Stein, J. L. 1981. "Speculative Price: Economic Welfare and the Idiot of Chance." Review of Economics and Statistics 63 (May): 223-32.

U.S. Department of Agriculture, Soil Conservation Service. 1961. "Land Capability Classification." Agricultural Handbook 210. Washington DC: U.S. Government Printing Office. __ 198 1. "Major Land Resource Areas of the United States." Agricultural Handbook 296. Washington D.C.: U.S. Government Printing Office.

Wheaton, W. C. 1982a. "Urban Residential Growth under Perfect Foresight." Journal of Urban Economics 12: 1-2 1.
---. 1982b. "Urban Spatial Development with Durable but Replaceable Capital." Journal of Urban Economics 12:53-67.

$\mathrm{Wu}$, J., and K. Segerson. 1995. "The Impact of Policies and Land Characteristics on Potential Groundwater Pollution in Wisconsin." American Journal of Agricultural Economics 77 (Nov.): 1033-47.

Wu, J., H. P. Mapp, and D. J. Bemardo. 1996. "Integrating Economic and Physical Models for Analyzing Water Quality Impacts of Agricultural Policies in the High Plains." Review of Agricultural Economics 18 (Sept.): 353-72. 